\title{
Political Media Images: Linguistic and Cognitive Aspects
}

\section{Evgeniya A. BARMINA}

Institute of Social Sciences and International Relations

Sevastopol State University

33, Universitetskaya str., Sevastopol, the Russian Federation

mar.indigo@mail.ru

\section{Nataliya A. MESTANKO}

Institute of Social Sciences and International Relations

Sevastopol State University

33, Universitetskaya str., Sevastopol, the Russian Federation nat.mestanko@yandex.ru

\section{Olga G. SKIDAN}

Institute of Social Sciences and International Relations

Sevastopol State University

33, Universitetskaya str., Sevastopol, the Russian Federation

$\underline{\text { skidan_ua@mail.ru }}$

\begin{abstract}
The paper focuses on linguistic and conceptual analysis of means of creating a politician's image in the mass media discourse, special attention being paid to manipulation techniques. Mass media have turned into the main means of political discourse realization; they rank political issues in order of importance thus shaping political opinions. The research into media discourse has shown that the main manipulative tools used as means of political informational pressure by American mass media are metaphors, pejorative lexical units, illusions, phraseological units, sophistries, rhetorical questions, parallel constructions, imperative constructions, forms of addressing the reader with the help of personal pronouns, authority support, quotations, presupposition impositions, numerical data and pseudo statistics. Mass media interpret current events to their advantage and this interpretation is represented as a universal truth. Being under constant pressure of mass media, most
\end{abstract}


of the recipients perceive the subjective evaluation of the presented information as the objective reality.

Keywords: mass media political discourse; media-image; conceptual metaphor; manipulation; manipulative means.

\section{Introduction}

The main functions of mass media comprise gathering, accumulation, storage, processing and broadcasting information. But the function of mass media as the main means of political discourse realization is seen as no less important. Mass media prove to be not only another political system institute, but are also considered to be the communicators of the system, which enable it to broadcast information. The audience perceives the information broadcast by mass media by reflection of its content in the minds of the audience. Thus, the well-rounded picture of current situation is created which comprises an array of continuously changing facts and events. The media information recipients develop the picture of the world. Media image is seen as the result of this development.

The relevance of this paper is attributed to the fact that research on the political discourse corresponds to the current trends in the contemporary pragmatics of the language and sociolinguistics. The research on linguistic means which are used with the aim of manipulation enables us to identify similarities and differences in the pictures of the world both of the recipients and the addresser.

Politics is getting more and more discursive these days. Mass media have turned into the main means of political discourse realization. Not only do they provide information and global awareness but also rank the political issues in order of importance thus shaping the political opinions. Moreover, mass media may impose their views and this way they may make the audience change their political viewpoints as it happens, for instance, when mass media develop the image of a politician. Journalists belong to symbolic elites, which play the essential role in the ideological supporting framework for the exercise or maintenance of power in our modern, information and communication societies (Van Dijk, 1989).

Human mind may be controlled via a variety of means including the linguistic ones. The linguistic means of mind control serve as the key subject of cognitive linguistics research.

The aim of the research is to conduct linguistic and conceptual analysis of means of creating a politician's image in the mass media discourse and to pay special attention to manipulation techniques in speech. 


\section{Literature Review}

Communicative means of mind control have long been the subject of research in terms of political discourse. The following researchers have contributed to this field of the research: Dotzenko (2000), Skovorodnikov (2012), Kopnina (Skovorodnikov, 2012), Nikitina (2006), Posternyak (2018), Boeva-Omelechko (Posternyak, 2018), Slavova (2015), Chilton (2017), Maalej (2011), A. Pluwak (2011), Snoeck Henkemans (2010; 2015). This field of research is of great interest for a reason. Nowadays most media have seen a shift in their function from informative, which used to be the leading one, to the function of mind control, which is getting more predominant.

According to Dotzenko (2000), manipulation is a means of psychological influence, which, if skillfully applied, leads to inciting intentions which another person initially failed to have. Manipulation may create ideas, associations, images, stereotypes which are able to change the recipients' attitudes towards any object as well as the media picture in general. And the recipient will remain unaware of these changes. According to Skovorodnikov, Kopnina (2012), manipulation is a type of linguistic persuasion which influences the recipient to the manipulator's advantage by means of particular linguistic resources.

Linguistic means of manipulation are classified according to the layers of the language system. Nikitina (2006) takes research into verbal communication instruments at the following levels: phonographic, lexical, grammatical, textual. Means of linguistic manipulation are most efficient at the lexical and textual levels.

The following linguistic means are used at the linguistic level:

- Manipulation using ideologically modal vocabulary. The category of ideological modality comprises a wide range of assessments with those defining political views and ideological values being among the top.

- Choice of words and word combinations which have the meaning of assessment and evaluation both with positive and negative connotations. This means is widely used in the informational texts as it complies with the functional goals of these texts and enables one to highlight the authors' viewpoint explicitly.

- The use of a variety of stylistic devices including metaphors, allusions, irony. Not only do these stylistic devices make the texts more expressive, but they also contain the author's attitude which is expressed implicitly. 
- Phrases which are built up according to special syntactical patterns including rhetorical questions, exclamations, inversion, parallel constructions. Exclamatory, interrogative sentences as well as sentences with inversion are frequently found in media texts, which is connected with the ability to enhance the impact and express the opinion.

Thus, if we look at language as a means of communicative persuasion, we should state that it is possible to impose either positive or negative attitude upon the readers, to change their outlook, stimulate emotional feedback, adjust their attitudes towards different objects and processes. This type of communicative persuasion is widely used when creating media images of politicians. One of the main tendencies in creating socio - political reality is to construct politicians' images by means of media discourse.

Much research is being taken into the meaning and methodology of the term "media image". Different understanding of the terms media and image predetermine variability of the "media image" internal meaning. We may consider "media image" both as the image which is created in media space and as the image which is perceived via media sphere.

Galinskaya (2013) investigated the two aspects of media image. On the general level, media image is defined as "the reality image which is created in all texts of the media sphere by journalists, bloggers etc."; on the specific level "media-image is made up of reality fragments which are found in the texts created by professional journalists alone therefore reflecting their views on life, values, political preferences as well as their psychological qualities". The journalists create media image deliberately using particular techniques, which are aimed at creating the required perception. Our research is based upon media image which is created by professional journalists.

The following qualities are typical of media image - it should be short-term, stereotypical, emotional, ambiguous, exaggerated (Galinskaya, 2013). These qualities enable media image to form media mentality whereby objective reality is substituted for media images broadcast by mass media. General public plays the key role in the process of creating a media image.

A wide range of lexical means aimed at expressing the evaluation is used in media texts. According to the author's attitude to the message, the evaluation may be positive, negative or neutral; considering impartiality it may be subjective, objective, or subjective-objective; considering emotions imparted it may be either rational or emotional. Moreover, the evaluation may be implicit, i.e. referring to the contextual rather than general meaning, or explicit, i.e. one of the semes contains this meaning. 
Media reality, which is created by means of media texts, is made up of reality images produced and broadcast for recipients via mass media. Local and international news reports influence both political and ideological views as well as opinions of the majority of the audience.

\section{Methods}

According to the approaches stated above, we posit the term "media image" as the reflection of objective reality in the mind of the native speakers, i.e.as the language consciousness fragments. Consequently, media image reconstruction is similar to concept reconstruction, which enables us to use cognitive linguistics methodology.

Structure is the main feature of the concept. It is the logical structure which predetermines the inner organization of the concept, which is not merely an amount of knowledge or comprehension or even the conjunction between those. Knowledge presentation framing forces researchers to explore the layers of concepts when modeling its structure.

Frame also makes up the basis of politician's media image model. The slots or this frame contain images which exist in understanding of general public and which are formed by mass media. For frame is a hierarchically organized cognitive unit, it makes it possible to systematize and structure both perception and knowledge of modeling object. The main qualities of frame are procedure, dynamics, and functionality.

Framing in conceptual content modeling is connected with conceptual modeling method, which refers to the theory of conceptual metaphor. This theory is the most productive means of conceptualization. This enables us to reconstruct conceptual metaphoric models, which are used to denote conceptual situations in terms of a discourse.

One of the brightest and efficient means of realization of the directive function in publicist style is the metaphor. In compliance with the cognitive theory of metaphor, we think metaphorically and therefore metaphors influence the associativity of our minds, this way they facilitate understanding. The main goal of using metaphors in media discourse is to create opinions, images, outlook using emotional and rational influence. Although the theory of conceptual metaphor was developed by Lakoff $(1980 ; 1993)$ and Johnson back in 1980, more and more research is being made into this phenomenon as it is capable of having great impact on ideology.

According to Popova (2009), "conceptual metaphor is a type of nomination whose leading function is to form concepts which are the verbalized notions that in form of the image contain the titles and understanding of the nomination subject about the qualities and type of the object of nomination. 
Such metaphor gives the title to denotation and simultaneously suggests a particular angle of vision".

The basis of conceptual metaphor is made up of associations, similarities and differences of processes which express the person's attitude towards a particular moment as well as understanding of the moment. What is typical of a conceptual metaphor is the fact that it lingers in a person's mind owing to its logical connection.

Conceptual metaphors serve as a structuring element of the text as they provide coherence and cohesion of the text as well as enhance the pragmatic potential of the text. The main role of the conceptual metaphors in media political text is to control minds which provides connection between politics and language. Researchers have yet to agree whether the process of detecting metaphors is subjective or objective.

Andrew Goatly (1997) considered philosophical aspects of objectivity and subjectivity of conceptual metaphors. He stated that conceptual metaphors could not be absolutely objective as we lack direct access to reality in media discourse and our psychological process is mediated by metaphorical structures. However, there are no reasons to state that subjectivity prevails in the conceptual metaphors as we build up metaphors using our experience which is universal. Therefore, we all speak a common metaphorical language.

Conceptual metaphor is a means of translating experience. It is essential to note that linguistic and cultural aspects of the society have a great impact upon the formation of conceptual metaphors. As a result, conceptual metaphor may be considered as an element of the society culture. Conceptual metaphor may be seen as a cognitive accumulator, which defines and control the communication between the author and the recipient. It may be seen as an intermediary in this communication for a reason. Conceptual metaphor is used as a means of persuasion or manipulation in media discourse. It enables one to combine the reality with experience and symbols as it is the mechanism that influences the formation of our worldview.

Metaphor is defined as a means of manipulating public opinion as one of the main qualities of media political discourse is manipulation. The researchers emphasize the fact that metaphors are schematic, which explains why they may be used in political texts. According to Malyukova (2010), metaphor is a ready-made cliché of mind. It makes it easier to be used by the manipulator than other linguistic means. Wishing to facilitate the process of understanding, the reader uses associations and analogies to define a particular process with the help of metaphor (which uses the qualities of the familiar processes) instead of digging deeper. 
Metonymy is also widely used in media political discourse. Both metaphor and metonymy make use of words or word combinations applied figuratively. The main difference between them is the fact that metaphors exert the transition using similarity in meaning whereas metonymy uses adjacency in time, space or logical sequence. Metonymy is conceptualization of one by means of its relation to another (Kövecses, 2005). The author takes some quality, which is clear and understandable, and uses this quality instead of the object as a whole or instead of another quality or part of this object. The most frequently used models of metonymical transference are "object instead of user" and "place instead of institution". According to Chudinov (2003), metonymy provides an effective way for pragmatic effect, owing to the latter the political picture of the world in the recipients' mind is changed.

Thus, metaphors and metonymies are among the brightest and the most efficient means of audience persuasion. They obtain an additional perlocutive effect in the political discourse, which is provided by special mechanism of manipulation. The author represents his viewpoint of the situation not directly but calls for particular positive or negative associations in the reader's mind, which influence the information evaluation.

\section{Results}

Emotional evaluating part plays an important role in creating a politicians' media image. That is the reason behind journalists using the resources of phraseology and stylistics, which provide metaphors, expressiveness, emotions, notability. If used correctly, lexical expressive means may play crucial part in shaping the public opinion, as the addressee of the message fails to analyze the information he/she receives in detail, but tends to react impulsively, therefore, gets more susceptible to encoded signals.

There are two ways of representing information in media political discourse. It may be represented openly using facts, which are justified, and direct evaluation, or discreetly by such linguistic means as tropes, which are evasive, but easily recognized and decoded by the target audience. The latter includes metaphors, epithets, hyperboles, periphrases, irony, comparisons, etc.

Research of American and British media discourse has shown that there are a large number of negative dominants in the images of Vladimir Putin and Donald Trump. Manipulative lexical units serve as the main instrument of political informational pressure of American mass media. The most frequently used manipulative means are metaphors, pejorative lexical units, allusions, phraseological units, sophisticisms, rhetorical questions, parallel and imperative constructions, 
addressing the readers using personal pronouns, using authority, quotations, imposing presuppositions, using numeric data and pseudo statistics.

\section{Discussion}

When the journalists create politicians media image they use metaphoric concepts in order not to describe the appearance of the politician, but to evaluate his actions, comparing his conduct with that of his predecessor, analyzing his professional qualities and interaction with other politicians.

For instance, in the articles published by the Daily Express, the image of a politician as a game player is created under the following headlines Russia threatens to send men to 'rescue' Western hostages, Putin is winning it on Ukraine.

Kremlin grandmaster president Vladimir Putin was playing a dangerous gambit last night as he threatened to edge the Ukraine conflict towards a full blown the war (Winter, 2014).

Creation of this image is based upon conceptual metaphor that politics is a game of chess. Relations between Russia and Ukraine are compared with a game of chess, where Vladimir Putin is a grandmaster, which highlights his intelligence and power. However, there are lexemes with negative connotation, which try to persuade the reader that the president of the Russian federation plays a dangerous game. One of the most efficient manipulative tools is metaphor, which is capable of influencing the readers' minds. It has a presupposed characteristic which are attributed to the described object.

In the chess game that is the Ukraine crisis, it's increasingly clear that Russian president Vladimir Putin hasn't thought his way through to the end game. He is aggressive in his moves, but also calculating. He wants success but not at any coast... Does he have a strategy to win this game, or is he now playing for some version of a draw? (Ignatius, 2014).

Here the writer uses adjectives with a negative connotation in order to substitute objective reality for his viewpoint. For the same reason she uses parallel constructions, which are based upon the principle of foregrounding, and have expressive function. Antithesis is used to create ambivalent image of the president. On the one hand, there is an image of an experienced game playing politician, which has been created in the same newspaper, this way the readers put their trust in the information. On the other hand, pejorative manipulative lexical units impose a negative image of the politician.

One more efficient tool of manipulation is a rhetorical question. It highlights the most essential components in the text. Rhetorical questions allegedly suggest that the reader choose the possible 
outcome, however, in fact, both variants of the response serve to create a negative image of the president.

Readers mind may also be controlled with the help of presupposition. The following example contains presupposition it's increasingly clear that, which imposes discreetly something that the readers might otherwise not have put their trust in.

The New York Times published an article entitled Away from Show of Diplomacy in Geneva, Putin Puts on a Show of His Own. This headline is a verbal embodiment of the conceptual metaphor POLITICS IS THEATRE (SHOW) (Herszenhorn, 2014). Conceptual metaphor is verbalized by such units as showman, as well as the metaphors Mr. Putin's show of bravado, question - and answers show (Herszenhorn, 2014).

No President has not lied, even Lincoln. But sometimes there really is something new under the political sun (Remnick, 2016).

Double negation No president has not lied in convergence with metaphor under the political sun highlights the negative aspects of the politician's image.

He lies to avoid. He lies to inflame. He lies to promote and to preen. Sometimes he seems to lie just for the hell of it. He traffics in conspiracy theories that he cannot possibly believe and in grotesque promises that he cannot possibly fulfill. When found out, he changes the subject - or lies larger (Remnick, 2016).

Anaphoric repetition he lies facilitates rooting of the necessary image. This effect is enhanced due to simple syntax. Short simple sentences stand out and attract the readers' attention. Parallel constructions (He traffics in conspiracy theories that he cannot possibly believe and in grotesque promises that he cannot possibly fulfill) are efficient in making the text more powerful and making the image brighter. It leaves a long-lasting memory in the mind of the readers and reflects the views of the writer.

The article Is Something Neurologically Wrong with Donald Trump? actualizes the concept MEDICINE. It makes use of metaphorical usage of military, sport, theatrical and medical terminology, which is familiar to the readers and enables readers to trust the media.

President Donald Trump's decision to brag in a tweet about the size of his "nuclear button" compared with North Korea's was widely condemned as bellicose and reckless. The comments are also part of a larger pattern of odd and often alarming behavior for a person in the nation's highest 
office....Trump's grandiosity and impulsivity have made him a constant subject of speculation among those concerned with his mental health (Hamblin, 2018).

Here the negative image is created by the content of the dual irony the size of his nuclear button. The negative image is supported by the adjectives with negative connotation bellicose, reckless, alarming.

The journalists frequently use stylistic devices and tropes in media political discourse. This way they create media image and public attitude to it. Stylistic devices reinforce a particular image of the politician in the minds of the recipients and are capable of changing their attitudes completely.

\section{Conclusion}

The research into media discourse has shown that negatively charged dominants prevail in the images of Vladimir Putin and Donald Trump. The main manipulative tools used as means of political informational pressure by American mass media are metaphors, pejorative lexical units, illusions, phraseological units, sophistries, rhetorical questions, parallel constructions, imperative constructions, forms of addressing the reader with the help of personal pronouns, authority support, quotations, presupposition impositions, numerical data and pseudo statistics.

Mass media have currently made a transition from a mere political system institution to the system communicators which broadcast information. Mass media interpret current events to their advantage and this interpretation is represented as a universal truth. Being under constant pressure of mass media, most of the recipients perceive the subjective evaluation of the presented information as the objective reality.

\section{References}

Chilton, P. (2017). Toward a Neuro-Cognitive Model of Socio-Political Discourse, and an Application to the Populist Discourse of Donald Trump. Langage et société, 2-3, 160-161. Retrieved from: https://www.cairn.info/revue-langage-et-societe-2017-2-page-237.htm (Accessed on October 11, 2019).

Chudinov, A.P. (2003). Metaforicheskaja mozaika v sovremennoj politicheskoj kommunikacii. Ural State Pedagogical University. (in Russian)

Dotzenko, E.L. (2000). Manipuljacija: psihologicheskoe opredelenie ponjatija. Psihologicheskij zhurnal, 4, 132-138. (in Russian) 
Galinskaya, T.N. (2013). Ponjatie mediaobraza i problema ego rekonstrukcii v sovremennoj lingvistike. Vestnik $O G U, 11(160), 91-103$.

Goatly, A. (1997). The Language of Metaphors. London: Routledge.

Hamblin, J. (2018). Is Something Neurologically Wrong with Donald Trump? The Atlantic. Retrieved from: $\quad$ https://www.theatlantic.com/health/archive/2018/01/trump-cogdecline/548759/ (Accessed on December 12, 2019).

Herszenhorn, D.M. (2014). Away from Show of Diplomacy in Geneva, Putin Puts on a Show of His Own. The New York Times. Retrieved from: https://www.nytimes.com/2014/04/18/world/europe/russia-ukraine.html (Accessed on February 2, 2019).

Ignatius, D. (2014). Putin is winging in Ukraine. The Washington Post. Retrieved from: https://www.washingtonpost.com/opinions/david-ignatius-putin-is-winging-it-onukraine/2014/05/08/d14dac64-d6f0-11e3-95d3-3bcd77cd4e11_story.html (Accessed on February 2, 2019).

Kövecses, Z. (2005). Metaphor and metonymy in cognitive linguistics. Cognitive Linguistics, 1334.

Lakoff, G. (1980). Metaphors We Live By. Chicago: Chicago University Press.

Lakoff, G. (1993). The Contemporary Theory of Metaphor. Metaphor and Thought. Cambridge: Cambridge University Press, 202-251.

Maalej, Z. (2011). Ideological and Non-ideological metaphors: A Cognitive-Pragmatic Perspective. Metaphors and Cognition. Morocco: Laboratory Publications: Linguistics and Communication Labs, 97-122. Retrieved from: https://www.researchgate.net/publication/259784312_Ideological_and_nonideological_metaphors_A_cognitive-pragmatic_perspective (Accessed on October 11, 2019).

Malyukova, D.S. (2010). Metafora v sisteme jazykovyh sredstv konstruirovanija obraza politika v sovremennom diskurse. Filologicheskie nauki. Voprosy teorii i praktiki, 1, 175-178. (in Russian) 
Nikitina, K.V. (2006). Politicheskij diskurs SMI i ego osobennosti, sozdajushhie predposylki dlja manipuljacii obshhestvennym soznaniem. Upravlenie obshhestvennymi i jekonomicheskimi sistemami: mnogopredmetnyj nauchnyj zhurnal. Orel: Orel GTU, 58-69. (in Russian)

Pluwak, A. (2011). The Linguistic Aspect of Strategic Framing in Modern Political Campaigns. Cognitive Studies. Warsaw: 11 SOW Publishing House, 307-319.

Popova, Z.D. (2009). Ocherki po kognitivnoj lingvistike. Voronezh: Istoki. (in Russian)

Posternyak, K.P. (2018). The Formation of the Image of Russia in the British Political Mass Media Discourse. Acta Scientiarum Language and Culture, 40(2), 41086. Retrieved from: https://www.researchgate.net/publication/329010034_The_formation_of_the_image_of_Rus sia_in_the_British_political_mass_media_discourse (Accessed on October 11, 2019).

Remnick, D. (2016). Introducing a New Series: Trump and the Truth. The New Yorker. Retrieved from: https://www.newyorker.com/news/news-desk/introducing-a-new-series-trump-andthe-truth (Accessed on February 2, 2019).

Skovorodnikov, A.P. (2012). Sposoby manipuljativnogo rechevogo vozdejstvija v rossijskoj presse. Politicheskaja lingvistika, 3. Retrieved from: https://cyberleninka.ru/article/n/sposobymanipulyativnogo-rechevogo-vozdeystviya-v-rossiyskoy-presse (Accessed on October 11, 2019). (in Russian)

Slavova, L.L. (2015). Image of a Leader's Linguistic Personality in Political Discourse. Cognition, Communication, Discourse. Series "Philology", 11. Retrieved from: https://periodicals.karazin.ua/cognitiondiscourse/article/view/11291 (Accessed on October 11, 2019).

Snoeck Henkemans, A.F. (2010). Manoeuvring Strategically with Metonymy in the Confrontation and Argumentation Stages of a Discussion. Understanding Argumentation: Work in Progress, 2(4). Retrieved from: https://www.uni$\underline{\text { saarland.de/fileadmin/user_upload/Institute/eir/Proceedings/Paper_Snoeck_Henkemans_Fra }}$ nziska.pdf (Accessed on October 11, 2019).

Snoeck Henkemans, A.F. (2015). Strategic manoeuvring with hyperbole in political debate. Understanding Argumentation: Work in Progress, 2(4). Retrieved from: https://www.unisaarland.de/fileadmin/user_upload/Institute/eir/Proceedings/Paper_Snoeck_Henkeans_Franz iska.pdf (Accessed on October 11, 2019). 
Van Dijk, T. (1989). Structures of Discourse and Structures of Power. Annals of the International Communication Association, 12(1). Retrieved from: http://citeseerx.ist.psu.edu/viewdoc/download?doi=10.1.1.651.2680\&rep=rep1\&type=pdf (Accessed on October 11, 2019).

Winter, S. (2014). Russia threatens to send men to 'rescue' Western hostages. The Daily Express. Retrieved from: https://www.express.co.uk/news/world/472663/Russia-threatens-to-sendmen-to-rescue-Western-hostages (Accessed on February 2, 2019). 